\title{
The Tissue-Specific Extinguisher Locus TSE1 Encodes a Regulatory Subunit of CAMP-Dependent Protein Kinase
}

\author{
Michael Boshart, Falk Weih, Mark Nichols, \\ and Günther Schütz \\ Institute of Cell and Tumor Biology \\ German Cancer Research Center \\ Im Neuenheimer Feld 280 \\ D-6900 Heidelberg \\ Federal Republic of Germany
}

\section{Summary}

The tissue-specific extinguisher locus TSE1, a dominant negative regulator of transcription in somatic cell hybrids, acts via a CAMP response element (CRE) to repress activity of a hepatocyte-specific enhancer. Guided by the antagonism between TSE1 and CAMP. mediated signal transduction, we identified the regulatory subunlt Rla of protein kinase A (PKA) as the product of the TSE1 locus. The evidence derives from concordant expression of RI $\alpha$ mRNA and TSE1 genetic activity, high resolution mapping of the Rl $\alpha$ gene and TSE1 on human chromosome 17, and the ability of a transfected RI $\alpha$ CDNA to generate a phenocopy of TSE1-mediated extinction. The mechanism of TSE1/ Rl $\alpha$-mediated extinction involves repression of basal PKA activity, reduced phosphorylation of CREB at Ser-133, and a corresponding reduction of in vivo protein binding at the target CRE.

\section{Introduction}

Fusion of distinctly differentiated somatic cells usually results in the loss of tissue-specific gene products of either parent, a phenomenon termed extinction. The concept that diffusible factors control cell type-specific gene expression in trans was originally derived from such cell fusion experiments (for reviews see Davis and Adelberg, 1973; Davidson, 1974; Gourdeau and Fournier, 1990). These systems provide a genetic approach for identifying trans-dominant regulatory factors. To date, a genetic analysis of extinction has been performed primarily in the hepatoma $\times$ fibroblast hybrid cell system. Killary and Fournier (1984) identified a locus on mouse chromosome 11 and its human homolog, chromosome 17, the tissue-specific extinguisher 1(TSE1), which coordinately represses hepatocyte-specific expression of several genes, including tyrosine aminotransferase (TAT) and phosphoenolpyruvate carboxykinase (PEPCK) (Lem et al., 1988; Thayer and Fournier, 1989; Ruppert et al., 1990). All of the genes repressed by TSE1 are normally inducible via the CAMP signal transduction pathway (Ruppert et al., 1990). Other extinguisher loci regulate expression of distinct sets of genes in hepatic cells, as all liver-specific traits are extinguished in karyotypically complete hepatoma $\times$ fibroblast hybrids (Chin and Fournier, 1987). For example, Tse-2 on mouse chromosome 1 represses expression of the serum albumin and alcohol dehydrogenase genes (Petit et al., 1986; Chin and Fournier, 1989).

Hepatoma microcell hybrids and deletion hybrids (Leach et al., 1989) that retain only human chromosome 17 or fragments thereof made it possible to analyze TSE1specific extinction effects, for example, to identify the target sequence for repression by TSE1 in the TAT gene. A cyclic AMP response element (CRE), an essential component of a hepatocyte-specific enhancer located $3.6 \mathrm{~kb}$ upstream of the TAT transcription start site, mediates repression by TSE1 (Boshart et al., 1990). Induction via the CAMP pathway reverses TSE1-mediated repression of CRE activity and gene expression (Thayer and Fournier, 1989; Boshart et al., 1990; Ruppert et al., 1990). This functional antagonism between TSE1 and the CAMP pathway is reflected by corresponding changes in protein binding in vivo at the CRE of the TAT gene. Increased protein binding at the TATCRE upon cAMP induction is also observed in vitro using crude hepatoma extracts (Weih et al., 1990). We have suggested that TSE 1 inhibits posttranslational modification, e. g., phosphorylation of a CRE-binding protein (CREB) by interfering in the CAMP signal transduction pathway (Boshart et al., 1990). Guided by this working hypothesis, we searched for the product of the TSE1 locus. As CAMP levels are not affected by TSE1 (Thayer and Fournier, 1989; M. B., unpublished data), we could exclude a mechanism lowering cAMP levels and therefore acting upstream of protein kinase $A(P K A)$ in the pathway. Consequently, we considered PKA inhibiting activities and protein phosphatases as promising candidates. The holoenzyme of PKA is a tetramer consisting of two regulatory and two catalytic subunits and is inactive in the absence of cAMP. Activation occurs when two cAMP molecules bind to each regulatory subunit, eliciting a reversible conformational change that releases active catalytic subunits (Taylor et al., 1990). Thus, regulatory subunits are conditional inhibitors of $\mathrm{C}$. Four distinct regulatory subunit genes have been identified, and they are differentially expressed (for review see McKnight et al., 1988a, 1988b). Here we provide evidence that the regulatory subunit Rla of PKA is the product of the TSE1 locus.

\section{Results}

Basal PKA Activity Is Reduced in TSE1+ Hybrids Owing to the functional antagonism between TSE1mediated extinction and cAMP signal transduction (Boshart et al., 1990), we tried to identify targets of TSE1 action in the CAMP pathway. We measured PKA activity in extracts from 7AD7 (TSE1 ${ }^{-}$) and 7AE27 $\left(\mathrm{TSE}^{+}{ }^{+}\right.$) hepatoma hybrid cells. These microcell hybrids retain part of human chromosome 17 with or without the chromosomal segment carrying human TSE1 on a rat hepatoma background (Leach et al., 1989). Basal PKA activity without addition of cAMP was 7-fold lower in 7AE27 (TSE1 ${ }^{+}$) cells (included in Table 1). Addition of $5 \mu \mathrm{M}$ cAMP abolished this difference, 

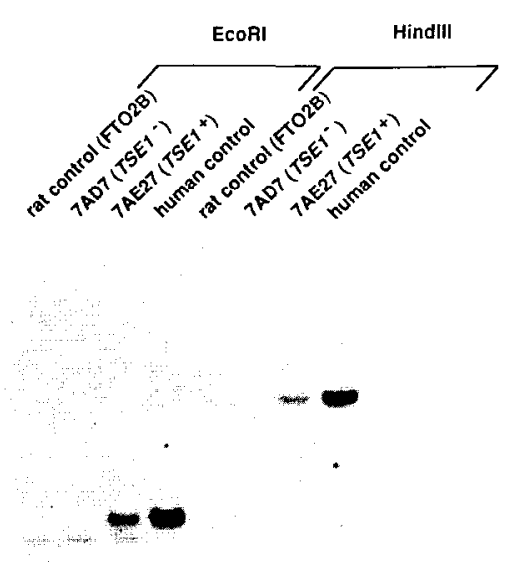

probe: human Rl $\alpha$

Figure 1. The Rla Gene Maps to Human Chromosome 17 Genomic DNAs were digested with EcoRI or HindIII as indicated and $8 \mu \mathrm{g}$ was analyzed by Southern blot hybridization with a 40 -mer oligonucleotide probe complementary to nucleotides 23-62 of the human Rla coding region (Sandberg et al., 1987). This is within the least conserved part of the regulatory subunit sequence, so that the RI $\beta$ gene or RIl genes were not detected. The human probe weakly crosshybridized to a rat RIa restriction fragment, which provided an internal reference. The result was confirmed with Pstl- and Sstl-digested samples (not shown).

indicating that expression of the catalytic subunit was similar in both cell lines. This was confirmed by measuring catalytic subunit mRNA levels (data not shown). As one explanation, we considered the possibility that increased regulatory subunit expression led to reduced basal PKA activity in 7AE27 $\left(\mathrm{TSE}^{+}{ }^{+}\right)$cells. This might occur if TSE1 either up-regulated a regulatory subunit encoded by the rat hepatoma genome or if TSE 1 itself encoded a human regulatory subunit. Therefore, we performed Southern blot hybridizations to test whether any of the four regulatory subunit genes mapped to human chromosome 17. With a mouse Rla probe (Clegg et al., 1987) we detected a human-specific restriction fragment in genomic DNA from 7AE27 $\left(\right.$ TSE1 $^{+}$) but not 7AD7 (TSE1) cells (data not shown). This result was confirmed with an oligonucleotide probe specific for human Rla (Figure 1). Thus, the human Rl $\alpha$ gene and TSE1 both map to a segment of chromosome 17 retained in 7AE27 (TSE1 $1^{+}$) but not in 7AD7 (TSE ${ }^{-}$) cells. A previous report had assigned a sequence recognized by an Rla probe to human chromosome 7 (Scambler et al., 1987). It is now clear that this sequence is the closely related RI $\beta$ gene expressed specifically in neuronal tissues (Clegg et al., 1988 and G. S. McKnight, personal communication). RII $\beta$ has also been mapped to human chromosome 7 (Scambler et al., 1987).

\section{Expression of RI $\alpha$ Correlates with the TSE1 Phenotype}

Using a human-specific $R \mid \alpha$ oligonucleotide probe, we detected Rla mRNA in 7AE27 (TSE1 ${ }^{+}$), but not 7AD7 (TSE1 ${ }^{-}$) cells (Figure 2B). Two human Rl $\alpha$ mRNAs (Sandberg et al., 1987) are generated by differential usage of polyadenylation signals (Sandberg et al., 1990). The Rl $\alpha$ mRNAs encoded by the rat genome were detected using a ratspecific Rla oligonucleotide probe. Three rat Rl $\alpha$ mRNAs, also generated by differential polyadenylation ( $\emptyset$ yen et al., 1988), were expressed at a very low level, and their expression was not affected by the presence of human TSE1 (Figure 2A). The levels of rat RIl $\alpha$ and rat RII $\beta$ mRNAs, as detected by specific oligonucleotide probes (Sandberg et al., 1988; Øyen et al., 1989), were also identical in 7AD7 (TSE1-) and 7AE27 (TSE1 ${ }^{+}$) cells (data not shown). Treatment of the cells with a CAMP analog or glucocorticoids did not change the level of any of the regulatory subunit mRNAs. However, high levels of RI $\alpha$ mRNA were found in both rat fibrosarcoma cells $(X C)$ and primary human fibroblasts (Figures $2 \mathrm{~A}$ and $2 \mathrm{C}$ ). Thus, high level expression of Rla mRNAs in fibroblasts and hepatoma $\times$ fibroblast microcell hybrids correlates with the $\mathrm{TSE}^{+}$phenotype of the cells.

We confirmed this correlation by analyzing a number of independently derived microcell hybrid clones (Figure 2C). The level of RI $\alpha$ mRNA in different TSE $1^{+}$hybrids was remarkably uniform and was maintained after subcioning and extensive passaging (compare 7AE27 and 7AE27/8, Figure 2C). This reflects the chromosomal stability of the microcell hybrids used in this work. In all TSE1+ hybrids, the level of Rla mRNA was about half the level in primary human fibroblasts. This was expected from gene dosage, as most microcell hybrids contain a single copy of human chromosome 17 or part of it (R. E. K. Fournier, unpublished data). Apparently, in hybrids the Rla gene on the transferred fibroblast chromosome continues to be expressed at a high level irrespective of low level expression of the Rla alleles in the hepatoma recipient cell. Expression of TSE1 activity must also be stably maintained by the fibroblast chromosome that mediates extinction.

\section{RI $\alpha$ and TSE1 Colocalize to a Small Segment of Human Chromosome 17}

To determine whether RI $\alpha$ mapped to the TSE1 locus, the map position of Rla was established relative to a set of cloned DNA markers for $17 \mathrm{q} 23-24$, which had been used to construct a physical map of the chromosome segment that includes human TSE1. The isolation of these DNA markers and the construction of the physical map will be described in detail elsewhere (B. E. K. Fournier, personal communication). In brief, chromosome fragment-containing hybrids with deletion breakpoints in $17 \mathrm{q}$ (Leach et al., 1989) had been scored for retention of the various DNA markers by Southern blot hybridization. The TSE1 phenotype of the cells had been determined by quantitation of TAT and PEPCK mRNA levels (R. E: K. Fournier, personal communication). We have used the Southern blot shown in Figure 3 toposition Rla relative to the various 


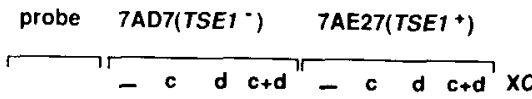

A

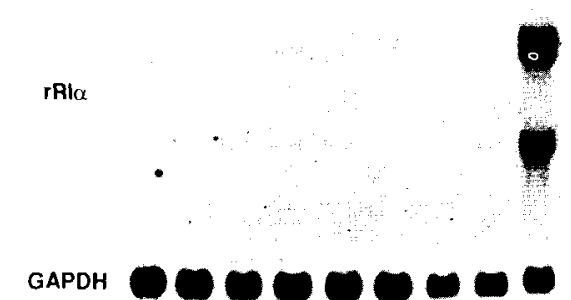

GAPDH

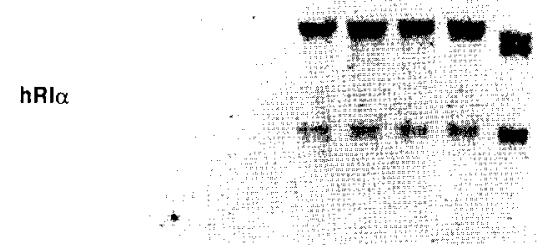

GAPDH
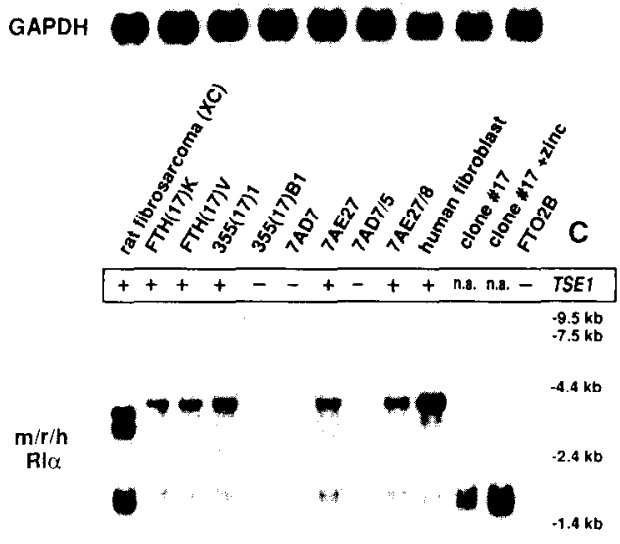

GAPDH

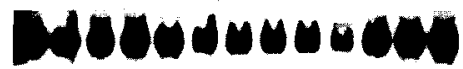

Figure 2. Expression of Rla mRNA Correlates with the TSE1Mediated Extinction Phenotype

(A and B) Total RNA (10 $\mu \mathrm{g})$ from uninduced (-) or induced (c, p-chlorophenylthio-cAMP; $d$, dexamethasone; $c+d$, both) cells was analyzed by Northern blot hybridizatlon. Induction conditions were as described by Ruppert et al. (1990). For (A), the probe was a 37-mer oligonucleotide complementary to nucleotides 118-154 of the rat Rla cDNA sequence (Kuno et al., 1987). The sizes of the three rat RI $\alpha$ mRNAs were reported as $3.2 \mathrm{~kb}, 2.9 \mathrm{~kb}$, and $1.7 \mathrm{~kb}$ ( $($ yen et al., 1988). The human Rla probe used for $(B)$ was the same as in Figure 1 , and crosshybridized with rat Rla mRNA (see XC fibrosarcoma lane). The sizes of the two human Rl $\alpha$ mRNAs were $3.0 \mathrm{~kb}$ and $1.5 \mathrm{~kb}$ according to Sandberg et al. (1987).

(C) The Northern blot (15 $\mu \mathrm{g}$ total RNA) was hybridized with a 40-mer oligonucleotide complementary to a sequence $100 \%$ conserved betwoen the rat, mouse, and human Rla coding regions (nucleotides 562-601 of the human Rla cDNA sequence of Sandberg et al., 1987) to allow direct comparison of the Rla mRNA levels in the various cell lines. $\mathrm{FTH}(17) \mathrm{K}, \mathrm{FTH}(17) \mathrm{V}$, and $355(17) 1$ are rat hepatoma $\times$ human fibroblast microcell hybrids retaining human chromosome 17 $355(17) B 1$ is a back-selectant from $355(17) 1$ that has lost the human chromosome. 7AD7/5 and 7AE27/8 are subciones from the deletion hybrids 7AD7 (TSE1 $1^{-}$) and 7AE27 $\left(\right.$TSE $\left.^{+}\right)$, respectively (Lem et al., 1988; Leach et al., 1989; Boshart et al., 1990). Human fibroblasts were derived from an oral mucosa biopsy. Clone $17(\# 17)$ is an FTO2B rat hepatoma transfectant overexpressing mouse Rla(mut). The TSE1 phenotype of the cell lines (as determined by measuring TAT mRNA
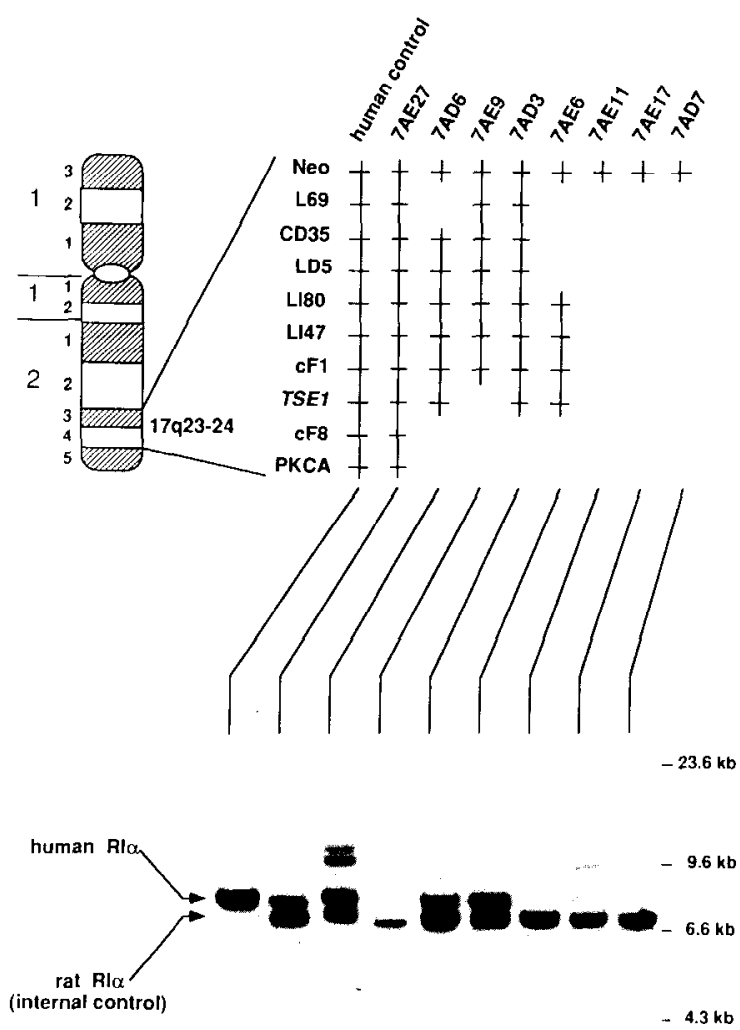

Figure 3. Colocalization of RI $\alpha$ and TSE1 on Human Chromosome 17 The results of marker analysis are summarized in the upper part of the figure. Nine DNA markers from the 17q23-24 region were arranged using Southern blot hybridization data from deletion hybrids described in Leach et al. (1989). TSE1 was phenotyped by measuring TAT and PEPCK mRNAs. EcoRI-digested DNA samples from these deletion hybrids were subjected to Southern blot hybridization with the human Rla oligonucleotide probe described in Figure 1. Two copies of the chromosomal segment carrying human Rla seem to be retained in deletion hybrids 7AD6 and 7AE6. The size marker is $\lambda$ DNA cut with HindIII. In some lanes partial digestion products are visible as additional bands in the $9-10 \mathrm{~kb}$ region.

DNA markers and to TSE1, resulting in the map shown schematically in Figure 3 . The Rla gene and human TSE1 colocalized to a segment of distal $17 q$ bounded by cosmid markers $\mathrm{CF} 1$ and $\mathrm{cF} 8$. Although the precise size of this interval is not yet known, it is likely to represent several hundred kilobase pairs of genomic DNA. Thus, Rl $\alpha$ and TSE1 colocalize to a small segment of the chromosome.

levels [data not shown]) is indicated as + or - or n.a. (not applicable). Rat fibrosarcoma ( $X C)$ cells have not been tested in a fusion assay, but the TSE1 phenotype is assigned by analogy with human and mouse fibroblasts. As size marker, the RNA ladder from Bethesda Research Laboratories was used.

All filters were rehybridized with a rat glyceraldehyde-3-phosphatedehydrogenase (GAPDH) probe (Fort et al., 1985; Ruppert et al., 1990) as the internal standard. The loading of human fibroblast RNA was controlled using ribosomal RNAs as reference (not shown). 


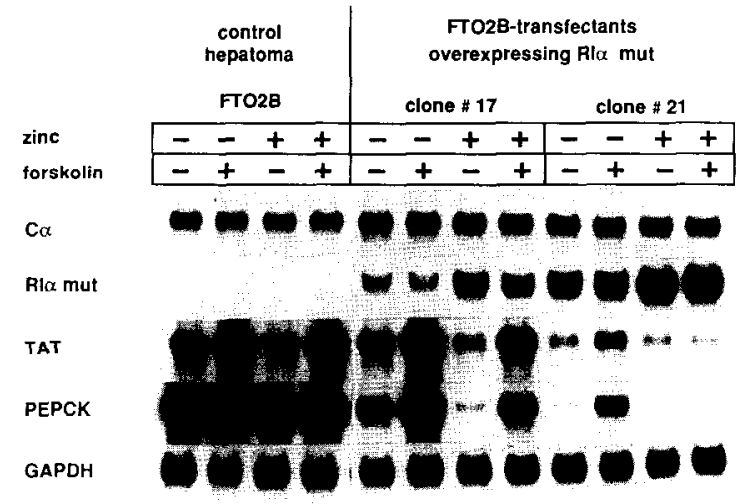

Figure 4. Northern Blot Hybridization Analysis of Stable Transfectants Expressing Mouse Rla(mut)

Where indicated, cells were treated with $100 \mu \mathrm{M} \mathrm{ZnCl}$ for $18 \mathrm{hr}$. Forskolin $(10 \mu \mathrm{M})$ or ethanol $(0.1 \%)$ as solvent control was added $2 \mathrm{hr}$ before RNA extraction. Total RNA $(10 \mu \mathrm{g})$ was probed for the catalytic subunit $C_{a}$ of PKA, for the regulatory subunit Rl $\alpha$, for TAT, and for PEPCK. The riboprobes used were described in Ruppert et al. (1990). All filters were rehybridized with a GAPDH probe as internal standard (only one example is shown).

\section{Overexpression of Rl $\alpha$ in Hepatoma Cells Results} in a Phenocopy of TSE1-Mediated Extinction

To determine whether Rla overexpression could produce a TSE $1^{+}$phenotype, we stably introduced an expression vector encoding mouse Rla under control of a zincinducible metallothionein promoter (Clegg et al., 1987; Mellon et al., 1989; kindly provided by G. S. McKnight) into FTO2B cells, which are the parental cells of the microcell hybrids used in this work. We used an Rl $\alpha$ cDNA with point mutations in each of the two CAMP-binding sites, encoding a protein that cannot bind CAMP. Upon induction with cAMP, the mutant Rl $\alpha$ subunit does not dissociate from the holoenzyme to release active catalytic subunits (Correll et al., 1989; Woodford et al., 1989). This allowed us to monitor the fraction of catalytic subunits bound to endogenous versus transfected regulatory subunits by measuring the residual cAMP response. Twenty-four transfectant clones were analyzed as described in the Experimental Procedures. Data for two clones, both showing about 3- to 4-fold zinc inducibility of Rla(mut) mRNA expression, are presented (Figure 4). As expected, increasing expression of Rla(mut) led to a reduction in basal PKA activity (Table 1). At high levels of Rla(mut) expression, CAMP-stimulated kinase activity was also reduced, indicating that at this level of expression a significant fraction of PKA holoenzyme contained mutant Rla subunits.

Down-regulation of PKA activity by Rla overexpression resulted in a proportional decrease in mRNA levels of TAT and PEPCK (Figure 4), two genes that respond both to CAMP and TSE1 (Lem et al., 1988; Ruppert et al., 1990). As both basal expression and cAMP inducibility of these genes depend on PKA activity, and as the TATCRE is essential for basal activity, CAMP response, and TSE1mediated repression of a liver-specific enhancer $3.6 \mathrm{~kb}$ upstream of the TAT gene (Boshart et al., 1990; Weih et al., 1990), we assayed the activity of a multimer of this CRE in clones 17 and 21. Enhancement of the herpesvirus thymidine kinase promoter activity by the multimerized $(5 \times)$ CRE was reduced proportionally with down-regulation of PKA activity (Figure 5). The quantitative correlations between Rl $\alpha$ (mut) mRNA expression, reduction of basal PKA activity, CRE-mediated transcriptional activation, and basal expression of the TAT and PEPCK mRNAs are shown in Figure 5. Two important conclusions can be drawn from these experiments: first, PKA activity not only mediates cAMP induction, but is required for basal expression of both TAT and PEPCK in hepatic cells. Second, overexpression of Rila resulted in a phenocopy of TSE1mediated extinction. For example, PEPCK mRNA levels are more dramatically reduced by TSE1 than are TAT mRNA levels (Thayer and Fournier, 1989). Rla overexpression in clone 21 led to complete repression of PEPCK mRNA, whereas the effect on TAT mRNA was less pronounced (Figures 4 and 5). The failure of complete repression of the TAT gene might be related to the presence of a second liver-specific enhancer at $-11 \mathrm{~kb}$ of the TAT gene that is not responsive to TSE1 (Nitsch et al., 1990; D. Nitsch, unpublished data). Reversal of the TSE1 effect by cAMP is another property of hepatoma microcell hybrids (Thayer and Fournier, 1989; Boshart et al., 1990; Ruppert et al., 1990). Owing to overexpression of mutant rather than wild-type Rla subunits in our transfectants, CAMP

\begin{tabular}{|c|c|c|c|c|}
\hline \multirow[b]{3}{*}{ Cell Line } & \multicolumn{4}{|c|}{ PKA-Specific Activity in $\mathrm{pmol} / \mathrm{min}$ per $\mathrm{mg}(\text { mean } \pm \mathrm{SD})^{3}$} \\
\hline & \multicolumn{2}{|c|}{ Untreated Cells } & \multicolumn{2}{|c|}{$\mathrm{ZnCl}_{2}$-Treated Cells ${ }^{b}$} \\
\hline & Basal $^{c}$ & $5 \mu \mathrm{M} \mathrm{CAMP}^{\mathrm{c}}$ & Basal $^{\mathrm{c}}$ & $5 \mu \mathrm{M} \mathrm{CAMP}^{\mathrm{c}}$ \\
\hline 7AD7 (TSE1) & $205 \pm 12$ & $1598 \pm 52^{d}$ & - & - \\
\hline 7AE27 $\left(\mathrm{TSE}^{+}{ }^{+}\right)$ & $28 \pm 4$ & $1735 \pm 10^{d}$ & - & - \\
\hline FTO2B & $184 \pm 12$ & $992 \pm 26$ & $157 \pm 6$ & $1029 \pm 40$ \\
\hline Clone 17 & $84 \pm 5$ & $932 \pm 56$ & $8 \pm 1$ & $435 \pm 8$ \\
\hline Clone 21 & $5 \pm 4$ & $133 \pm 22$ & $3 \pm 2$ & $24 \pm 5$ \\
\hline \multicolumn{5}{|c|}{$\begin{array}{l}\text { "Extracts were prepared and protein kinase was assayed in triplicates as described in the Experimental Procedures. SD, standard deviation. } \\
\text { " } \mathrm{ZnCl}_{2}(100 \mu \mathrm{M}) \text { was added to the medium } 21 \mathrm{hr} \text { prior to harvest to induce the metallothionein promoter driving Rla(mut) expression. } \\
\text { "The activities are PKA specific, as each sample was measured in parallel in the presence of the PKI(1-31) inhibitor peptide (Scott et al., 1986; } \\
\text { Grove et al., 1987). Only the inhibitable activity is displayed. } \\
\text { "The dose response curve for PKA activation by CAMP was not different for 7AD7 (TSE1-) and 7AE27 (TSE1+) extracts (data not shown). }\end{array}$} \\
\hline
\end{tabular}



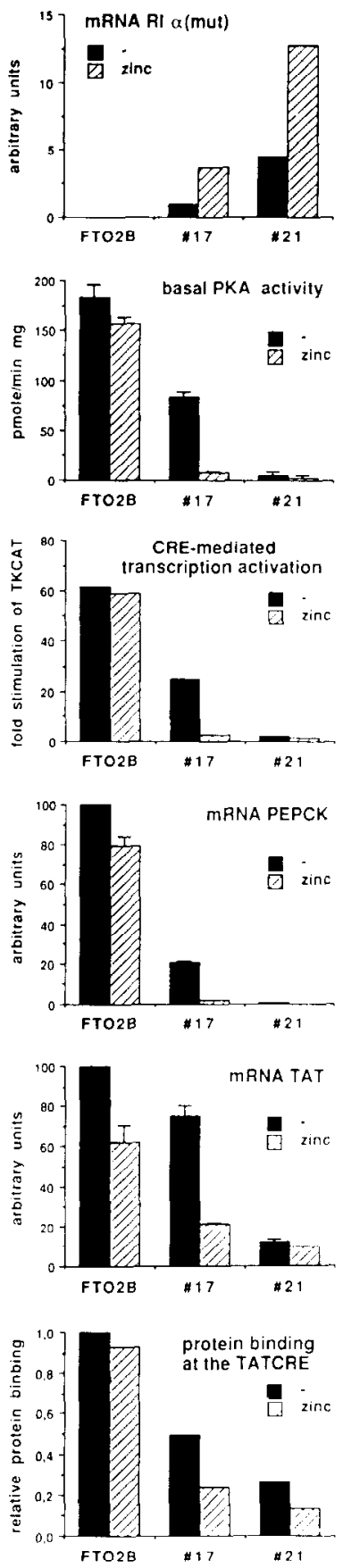

Figure 5. Summary of Phenotypes in Pla Transfectant Clones 17 and 21

The mRNA levels were quantitated by excising and counting the bands from the Northern blots shown in Figure 4. For TAT and PEPCK, two independent filters were quantitated (indicated by error bars), and the values for untreated FTO2B cells were arbitrarily defined as $100 \mathrm{U}$. PKA activities (mean \pm standard deviation) were taken from Table 1 CRE-mediated transcriptional stimulation was determined by transient transfection of a CAT construct with five tandem copies of a TATCRE oligonucleotide upstream of the herpesvirus thymidine kinase promoter $(5 \times \mathrm{BI})$, as described in the Experimental Procedures. For each cell line and treatment, the fold stimulation by the multimerized CRE was calculated by setting the value for the control construct with the thymidine kinase promoter alone (pBLCAT5) to 1 . The constructs are described in Boshart et al. (1990) and Ruppert et al. (1990). The values for relative protein binding were taken from Figure 6. only partially reverses negative regulation in clones 17 and 21 (see Table 1 and Figure 4).

Quantitatively, the extinction phenotypes of microcell hybrids and the phenotype of transfectant clone 17 cells were very similar (Figures 4 and 5; Boshart et al., 1990; data not shown). Therefore, we directly compared Rla mRNA levels in TSE1+ microcell hybrids and clone 17 using an oligonucleotide probe homologous to a region of Rla mRNA that is $100 \%$ conserved between rat, mouse, and human (see Figure $2 \mathrm{C}$ ). Rla mRNA expression and basal kinase activity (Table 1) were both in the same range in TSE ${ }^{+}$microcell hybrids and in clone 17 cells. This indicates that the level of Rl $\alpha$ expression in TSE $1^{+}$microcell hybrids is sufficient to confer the TSE1 phenotype. Thus, Rla fulfills functional criteria for being a product of the TSE1 locus.

Effects of TSE1/RI $\alpha$ on Protein Bound to the TATCRE In Vivo and on Phosphorylation of CREB at Ser-133 We previously reported that protein binding at the TAT$\mathrm{CRE}$ in vivo was strongly reduced in $7 \mathrm{AE27}\left(\mathrm{TSE}^{+}\right)$versus 7AD7 (TSE1-) cells (Boshart et al., 1990) and was inducible by CAMP (Weih et al., 1990). Overexpression of Rla in hepatoma transfectants also led to reduction of in vivo protein binding (as assayed by methylation protection) at the TATCRE (Figure 6). In clone 17, in vivo protein binding was reduced after zinc induction of Rla expression. In clone 21, protein binding at the TATCRE was almost completely abolished and the pattern was similar to that of the fibrosarcoma cells used as negative control. We conclude that basal and CAMP-induced protein binding at the TATCRE in vivo are dependent on PKA activity and that TSE1/ Rla plays a key role in cell-specific control of basal PKA activity. Furthermore, we have shown that CREB purified from rat liver or brain binds to the TATCRE, and that binding is strongly enhanced by PKA-mediated phosphorylation at Ser-133 (M. N. et al., submitted). Thus, the in vivo and in vitro results are concordant, suggesting that CREB binds to the TATCRE in vivo.

We have therefore analyzed the state of phosphorylation of CREB at Ser-133 in vivo. After labeling cells with [ $\left.{ }^{32} \mathrm{P}\right]$ orthophosphate, CREB was immunopurified, digested with trypsin, and the peptide carrying Ser-133 was identified by two-dimensional peptide mapping (Figure 7). Phosphorylation at Ser-133 was clearly reduced in 7AE27 $\left(\mathrm{TSE}^{+}{ }^{+}\right)$ cells and in clone 21 cells (overexpressing Rl $\alpha$ ) relative to parental hepatoma cells. As expected, forskolin induction of 7AE27 ( $\mathrm{TSE}^{+}$) cells resulted in increased phosphorylation of CREB at Ser-133. We quantitated phosphorylation at Ser-133 by densitometric scanning of the autoradiograms and compared the values with the quantitated protein binding at the TATCRE. The correlation between the extent of CREB phosphorylation in vivo and binding at the TATCRE in vivo is striking (Figure 7). We have also shown that the state of phosphorylation of purified CREB affects binding to the TATCRE in vitro (M. N. et al., submitted). In summary, TSE1/Rla acts by inhibition of PKA-mediated phosphorylation at Ser-133 of the transcription factor CREB and consequently by reducing binding to the TATCRE. 


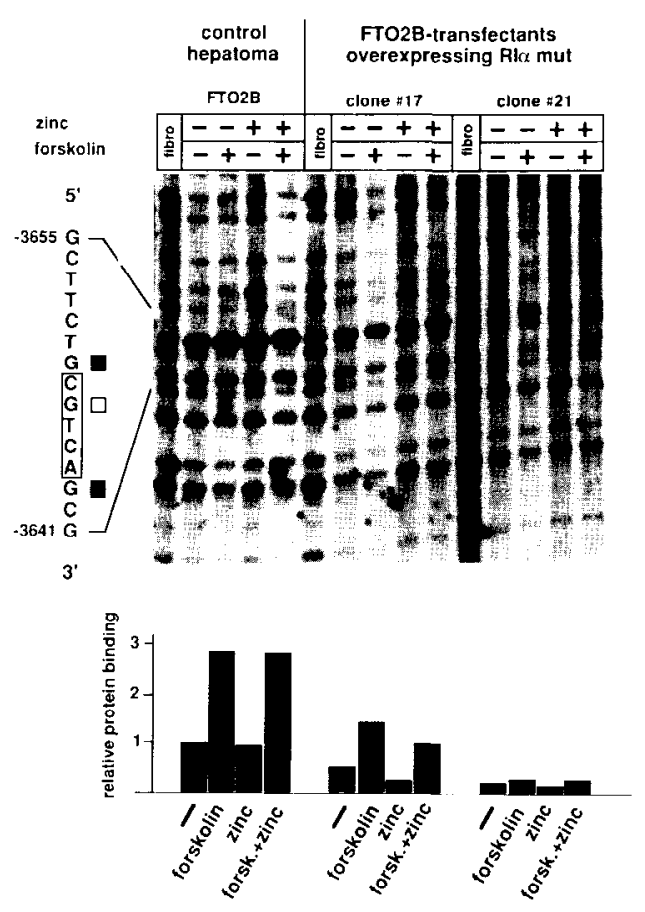

Figure 6. The In Vivo Footprint at the TATCRE Disappears upon Down-Regulation of PKA Activity

FTO2B, clone 17, and clone 21 cells were cultured for $18 \mathrm{hr}$ in serumfree medium with or without $25 \mu \mathrm{M} \mathrm{ZnCl}$, then induced with $20 \mu \mathrm{M}$ forskolin for $30 \mathrm{~min}$ or treated with $0.1 \%$ ethanol as solvent control. Cells were reacted with DMS and prepared for genomic footprinting as described in Becker and Schütz (1988). Thirty micrograms of Styl cut genomic DNA per lane was electrophoresed on a $6 \%$ denaturing polyacrylamide gel. After electroblotting and covalent cross-linking to a nylon membrane, hybridization was performed with a single-stranded cDNA probe (Weih et al., 1990) complementary to the sequence from -3516 to 3643 of the upper strand. Guanosine $(G)$ residues from -3619 to -3675 of the upper strand are visible on the autoradiogram. The pattern of purified genomic DNA reacted in vitro with DMS was indistinguishable from the XC rat fibrosarcoma (fibro) control lanes (not shown). Altered DMS reactivity of guanosines is marked with closed squares for enhancements and with open squares for protections. Numbers indicate the positions in base pairs relative to the start site of transcription. The part of the sequence homologous to the CRE consensus is boxed. Relative protein binding was quantitated by densitometric scanning and calculated as the ratio between the intensities of the enhanced $G$ at -3649 and the protected $G$ at -3647 . The ratio for $X C$ fibrosarcoma cells (fibro, negative control) was 0.74 (average of six XC lanes). The ratio for uninduced FTO2B cells was 8.1 and defined as one relative protein binding unit.

\section{Discussion}

Here we demonstrate that the tissue-specific extinguisher locus TSE1 encodes the regulatory subunit RI $\alpha$ of cAMPdependent protein kinase. In an independent effort to clone the TSE1 locus, Fournier and collaborators have isolated several cDNAs of genes expressed in 7AE27 $\left(\mathrm{TSE}^{+}{ }^{+}\right.$) cells but not in 7AD7 (TSE1 ${ }^{-}$) cells. One of these clones maps concordantly with TSE1 on a map of human chromosome 17 and turned out to encode Rla (R. E. K. Fournier, personal communication). Both approaches led to identification of Rla as the product of the TSE1 locus and reveal for the first time the molecular nature of an

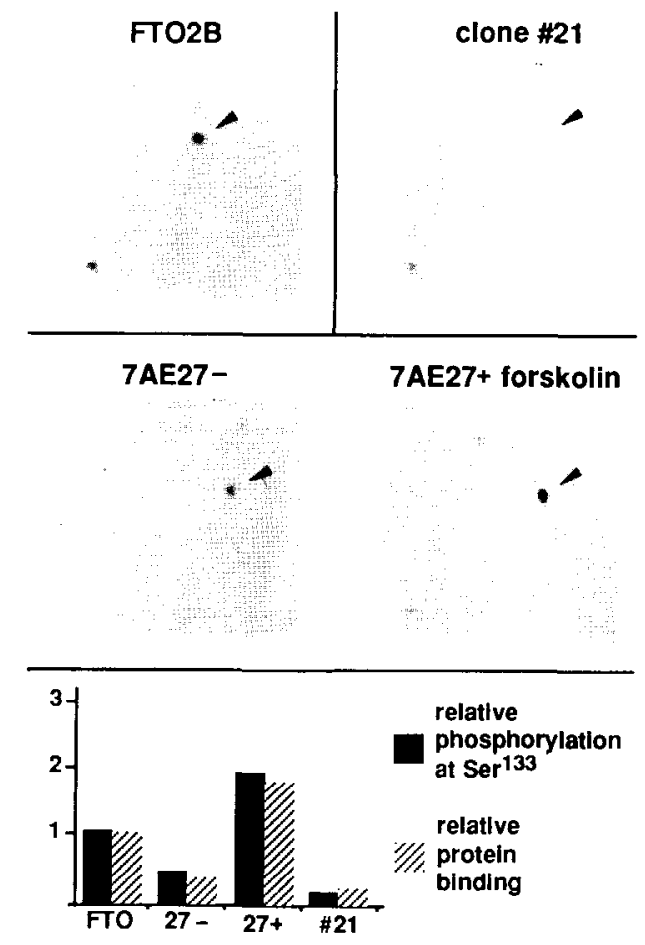

Figure 7. TSE1/Ria Affects In Vivo Phosphorylation of CREB at Ser-133

Cells were labeled in vivo with ${ }^{32} \mathrm{P}$ ]orthophosphate as described in the Experimental Procedures and induced with $10 \mu \mathrm{M}$ forskolin for $10 \mathrm{~min}$ where indicated. Immunopurification of CREB, trypsin digestion, and two-dimensional phosphopeptide mapping were performed as outlined in the Experimental Procedures. The identity of the spot representing the tryptic peptide RPSYR containing Ser-133 (arrowhead) was verified by mixing experiments with purified CREB protein and a synthetic peptide (amino acids 124-136; Gonzales and Montminy, 1989) both labeled with the purified catalytic subunit of PKA and then trypsinized (M. N. et al., submitted). CREB seems to be phosphorylated in vivo at additional Ser positions by other protein kinases (Lee et al., 1990). The tryptic peptides containing these phosphoamino acids are insoluble under our conditions and could not be analyzed with this method. Traces of this material are visible at the site of sample application in the lower left corner. The spots representing phosphorylation at Ser-133 were quantitated for each sample by densitometric scanning, and relative values were calculated by arbitrarily setting CREB phosphorylation in FTO2B cells to 1. For comparison, the diagram includes quantitative results from in vivo footprinting experiments (relative protein binding values taken from Figure 6 and from Boshart et al. [1990] for cell line 7AE27 $\left[\right.$ TSE $\left.^{+}\right]$).

extinguisher locus. This exemplifies the usefulness of somatic cell hybrids for identification of trans-dominant regulatory factors. In mammalian cells, regulatory mutants cannot be readily obtained. Therefore, somatic cell hybrids are valuable tools for the analysis of tissue-specific gene expression, allowing the identification of dominant regulatory factors irrespective of their mode of action.

The Mechanism of TSE1-Mediated Extinction The extinction phenotype in microcell hybrids results from differential expression of Rla/TSE in hepatoma cells versus fibroblasts, and from stab́le epigenetic maintenance of the high fibroblast-specific level of Rla expression in 
hybrids. High expression of Rl $\alpha$ does not necessarily lead to an increase of the steady-state level of Rla protein, as rapid degradation of free $\mathrm{RI}$ regulatory subunits seems to adjust the level of regulatory to that of catalytic subunits of PKA (Steinberg and Agard, 1981; Uhler and McKnight, 1987; Otten and McKnight, 1989). However, an excess of regulatory over catalytic subunit synthesis lowers the amount of free, catalytically active catalytic subunits of PKA. Therefore, basal PKA activity is low in cells with high expression of Rl $\alpha / T S E 1$ (see Table 1). In these cells, phosphorylation of Ser-133 of the transcription factor CREB is reduced (Figure 7). CREB purified from rat brain (Yamamoto et al., 1988) and from rat liver (M. N. et al., submitted) is a substrate for PKA, and phosphorylation at Ser-133 strongly increases the binding affinity for certain CRE sequences, including the TATCRE (M. N. et al., submitted). In addition, phosphorylation at Ser- 133 is required for transcriptional activation by CREB (Gonzalez and Montminy, 1989). Down-regulation of basal PKA activity by high expression of RI $\alpha /$ TSE 1 reduces protein binding at the TATCRE in vivo and lowers basal transcriptional activation mediated by the TATCRE, which is the target for repression by TSE1. The perfect correspondence between in vitro and in vivo results (Boshart et al., 1990; Weih et al., 1990; this work; M. N. et al., submitted) indicates that CREB does bind the TATCRE in vivo. The TATCRE is essential for the function of a liver-specific enhancer at $-3.6 \mathrm{~kb}$ of the TAT gene (Boshart et al., 1990), and TAT gene expression thus depends on basal PKA activity. TSE1-mediated extinction results from reduced PKA activity and consequently reduced CREB phosphorylation. This mechanism explains why TSE1-mediated repression is reversible by cAMP (Thayer and Fournier, 1989; Boshart et al., 1990; Ruppert et al., 1990). The observation that all TSE1-responsive genes identified so far are inducible by CAMP (Ruppert et al., 1990) suggests that TSE1 may repress transcription of these genes by the same mechanism, i.e., inhibition of CREB phosphorylation. We anticipate that other transcription factors that require phosphorylation by PKA for their activity may also respond to Rlal TSE1.

The mechanism of extinction has also been investigated in hybrids between fibroblasts and pituitary cells, lymphoid cells, or hepatoma cells expressing growth hormone, immunoglobulin genes, or albumin, respectively. In those hybrids the transcription rate or mRNA level of a tissuespecific transcription factor required for expression of these genes (GHF-1, OCT2, or HNF1, respectively) was down-regulated (McCormick et al., 1988; Junker et al., 1988; Bergman et al., 1990; Junker et al., 1990; Cereghini et al., 1990). Extinction can also be mediated by activation of silencer-like target sequences (Triputti et al., 1988; Zaller et al., 1988; Yu et al., 1989). Extinguisher loci have not yet been genetically defined in these systems, nor is it known how many intermediate regulatory steps are involved.

In the case of RI $\alpha / T S E 1$, the cascade of events leading to extinction is short: inhibition of a kinase (PKA) precludes phosphorylation of a transcription factor (CREB). It has been shown that inhibition of PKA can affect basal tran- scriptional activity of several cAMP-regulated promoters (Day et al., 1989; Grove et al., 1989; Mellon et al., 1989). Here we show that the activity of a CRE can be either constitutive or conditional depending on the level of basal PKA activity. This suggests that the same factor (CREB) is required both for basal CRE-mediated activation and cAMP inducibility.

\section{The Physiological Role of Rl $\alpha / T S E 1$}

The mechanism by which Rla/TSE1 controls gene expression in cell hybrids is likely to be part of the mechanism normally determining cell type-specific gene expression. Modulation of basal PKA activity by differential expression of RIa/TSE1 may contribute to tissue-specific control of expression of genes like TAT and PEPCK, which are dependent on PKA. Indeed, Rl $\alpha$ mRNA levels in adult mouse liver seem lower than in most other organs (M. B. and S. Ruppert, unpublished data). Tissue-specific control of gene expression usually results from the combined action of several factors whose distribution is often not strictly cell type specific (Dynan, 1989). For example, in the liverspecific enhancer at $-3.6 \mathrm{~kb}$ of the TAT gene, the mutual dependence of a CRE and a second essential and cellspecific element forms the basis of specificity for highly differentiated hepatoma cells (Boshart et al., 1990).

Another possible function of Rla/TSE1 is suggested by a number of observations regarding developmental activation of the TAT gene. TAT expression is not detectable before birth, but increases rapidly within the first hours postnatally (Greengard, 1970). This is accompanied by an increase in the newborn of hormones acting via the cAMP pathway, owing to postnatal hypoglycemia. These hormones seem to play a role in triggering the developmentally programmed onset of expression, as premature activation of the TAT gene can be elicited by administration of CAMP in utero (Greengard, 1970; Ruiz-Bravo and Ernest, 1982). TSE1 activity, as determined by the fusion assay (Peterson and Fournier, 1989), and Rl $\alpha$ expression (data not shown) are high in mouse hepatoma cells expressing fetal liver markers but low in adult hepatocytes (Gourdeau et al., 1989). Thus, Rla/TSE1 may play an important role in repressing the TAT gene in fetal liver before birth. The burst of hormones acting via CAMP could be sufficient to induce the gene shortly after birth. Mechanistically, this is analogous to extinction and reversal of extinction by CAMP in cell hybrids. A decrease of Rl $\alpha / T S E 1$ expression around birth might then establish a basal level of PKA activity sufficient for adult TAT gene expression. Increased catalytic subunit expression, decreased expression of other regulatory subunits, or elevated levels of cAMP in adult liver (Wittmaack et al., 1983) might also contribute to establishment of higher basal PKA activity after birth. We are currently investigating the developmental profile of regulatory and catalytic subunit expression in the liver by in situ hybridization. The same mechanism might also control developmental activation of the PEPCK gene shortly after birth. McGrane et al. (1990) have shown with transgenic mice that $a-460 /+73$ PEPCK promoter fragment is sufficient to confer a 200-fold increase in transgene mRNA after birth. PEPCK promoter fragments as small as -200 I 
+73 seem to be responsive to TSE1 in microcell hybrids (Thayer et al., 1990; R. E. K. Fournier, unpublished data). Clearly, the role for TSE1 response and developmental activation of the CRE at -90 in the PEPCK promoter has to be investigated, as PEPCK expression is dependent on PKA activity (see Figure 3).

The genetic evidence for a specific role of Rla/TSE1 in cell differentiation highlights the versatility of PKA in regulating cellular processes. The evolution and conservation of four regulatory subunits $(R|\alpha, R| \beta, R\|\mid \alpha, R\| \beta)$, each encoded by a separate gene, may have been necessary to accomplish such diverse functions as regulation of intermediary metabolism (Krebs and Beavo, 1979) and neuronal functions including learning (Drain et al., 1991) and gene transcription in the nucleus. Distinct tissue-specific expression patterns of each of the four isoforms have been found (McKnight et al., 1988a, 1988b; Cadd and McKnight, 1989). Available evidence suggests that cells can preferentially assemble RII holoenzyme and may only form Rla holoenzyme when catalytic levels exceed RII subunit levels (Otten and McKnight, 1989). The Rl $\alpha$ subunit is more susceptible to degradation when not complexed with the catalytic subunit (Steinberg and Agard, 1981). Thus, Rla may have a compensatory role, adjusting the total amount of regulatory subunits in the cell to that of catalytic subunits. Our results suggest that tissue-specific regulation of the level of Rl $\alpha$ expression, by determining the stringency of this adjustment, can control the basal activity of PKA and thereby affect gene expression.

\section{How Is Rla/TSE1 Expression Regulated?}

The transcriptional activity of the Rla/TSE1 gene on human fibroblast chromosome 17 is preserved when this chromosome is transferred via microcell fusion into the nucleus of a hepatoma cell that expresses RIa/TSE1 at a very low level. Thus, two mitotically stable, epigenetic states of gene expression coexist and are inherited in cis. This unusual regulatory behavior is required for any extinguisher locus to be detectable in the microcell hybrid assay system. Such a locus must be marked in some way that facilitates assembly of the locus in the appropriate transcriptional state following replication. This imprinting could be a covalent modification of the DNA, or a protein complex that is semiconservatively segregated to each strand during replication and serves as a template for its own reassembly (further possibilities are discussed by Pillus and Rine, 1989). As Rl $\alpha$ has a very GC-rich promoter region characteristic of "housekeeping" genes (Nowak et al., 1987; McKnight et al., 1988b), we considered methylation of the weakly expressed Rl $\alpha$ gene in hepatoma cells a possibility of marking the locus. However, when hepatoma cells were treated with 5-azacytidine to demethylate CpG dinucleotides, we could not observe any increases in Rlo. expression (data not shown). Thus, the nature of the epigenetic change that characterizes RIa/TSE1 gene activity remains to be defined.

\section{Experimental Procedures}

Cell Culture and Transfections

The rat hepatoma line FTO2B was described by Killary and Fournier
(1984) and the 7A series of deletion hybrids (including 7AD7 and 7AE27) by Leach et al. (1989). The microcell hybrids FTH(17)K, $\mathrm{FTH}(17) \mathrm{V}$, and $355(17) 1$ were constructed as outlined by Leach et al. (1989). 355(17)B1 was backselected from $355(17) 1$ as described (Killary and Fournier, 1984). Hepatoma cells were cultured in 1:1 (v/v) Dulbeccu's modified Eagle's medium (DMEM):Ham's F12. For the rat fibrosarcoma line XC (Svoboda, 1960) and human fibroblasts, DMEM was used. Media were supplemented with $10 \%$ fetal bovine serum, $100 \mathrm{U} / \mathrm{ml}$ penicillin, $100 \mu \mathrm{g} / \mathrm{ml}$ streptomycin, $10 \mathrm{mM}$ HEPES (pH 7.4), and $2 \mathrm{mM}$ glutamine. The medium for microcell hybrids also contained $800 \mu \mathrm{g} / \mathrm{ml} \mathrm{G418}$ (GIBCO, Bethesda Research Laboratories). Cells were grown at $37^{\circ} \mathrm{C}$ in $5 \% \mathrm{CO}_{2}$. For transient transfections, we used the lipofection procedure described by Boshart et al. (1990). Where indicated, $\mathrm{ZnCl}_{2}$ was added to $25 \mu \mathrm{M}$ with the DNA/Lipofectin mix. After $18 \mathrm{hr}$, fresh serum-free medium (with or without $25 \mu \mathrm{M} \mathrm{ZnCl}_{2}$ ) was added. Cell extracts were prepared after $48 \mathrm{hr}$, and CAT activity and protein were quantitated as described (Boshart et al., 1990)

\section{Stable Clones Overexpressing Rla}

The construct MT-REV(AB)neo, kindly provided by G. S. McKnight, contains a mouse Rla CDNA with point mutations in each cAMPbinding site (Clegg et al., 1987; Mellon et al., 1989) driven by the mouse metallothionein I promoter plus an SV40 promoter/enhancer-driven neo gene. This construct was linearized at a unique Scal site and introduced into FTO2B rat hepatoma cells by electroporation as described in Boshart et al. (1990). Cells were plated at a density of $10^{6}$ per $150 \mathrm{~mm}$ dish and 3 days later subjected to selection with $800 \mu \mathrm{g} /$ $\mathrm{ml} \mathrm{G418.} \mathrm{Individual} \mathrm{colonies} \mathrm{were} \mathrm{picked,} \mathrm{expanded,} \mathrm{and} 24$ c.lones were assayed by transient transfection (with and without $\mathrm{ZnCl}_{2}$ induction) for CRE-mediated transcriptional activation. For this purpose the lipofection procedure was scaled down and performed in 24-well cell culture plates $\left(3 \times 10^{5}\right.$ cells per well). A multimerized CRE upstream of the herpesvirus thymidine kinase promoter $(6 \times \mathrm{BI}$, Boshart et al., 1990) was linked to the luciferase gene and used as reporter. Cells were lysed in situ in the wells with $100 \mathrm{mM}$ potassium phosphate $(\mathrm{pH}$ 7.8), $1 \mathrm{mM} \mathrm{DTT,} 1 \%$ Triton $\mathrm{X}-100$ and assayed directly for luciferase activity as described (de Wet et al., 1987). Most clones showed reduced luciferase activity when compared with the parental FTO2B hepatoma line, and a few showed further down-regulation of luciferase activity after $\mathrm{ZnCl}_{2}$ induction of Rl $\alpha$. Thus, CRE-mediated transcriptional activation was regularly affected in Pla transfectants. Three clones (12, 17 , and 21) were analyzed in detail. Clone 12 is not shown in this paper, since the phenotype is almost identical to clone 17. Forskolin (Calbiochem) was used to raise intracellular levels of CAMP (Seamon et al., 1981).

\section{CAMP-Dependent Protein Kinase Enzyme Assays}

Cells were harvested and lysed as described by Uhler and McKnight (1987): Sonicated lysates were cleared by a $433,000 \times \mathrm{g}$ spin for 20 min at $2^{\circ} \mathrm{C}(100,000 \mathrm{rpm}$ in a Beckmann TL100.2 rotor), diluted to 2 $\mu \mathrm{g} / \mathrm{ml}$ protein with lysis buffer, and frozen in liquid nitrogen. Assays $\left(50 \mu \mathrm{l}\right.$ total volume) were performed for $10 \mathrm{~min}$ at $30^{\circ} \mathrm{C}$ and contained $10 \mathrm{mM}$ Tris (pH 7.4), $5 \mathrm{mM} \mathrm{Mg}$ acetate, $5 \mathrm{mM} \mathrm{DTT}, 250 \mu \mathrm{M}$ 3-isobutyl-1methylxanthine, $2.5 \mathrm{mM} \mathrm{NaF}, 100 \mu \mathrm{M}$ ATP including $0.75 \mu \mathrm{Ci}$ of $\left[\gamma^{32} \mathrm{P}\right] A T P, 500 \mathrm{mM}$ Kemptide (LRRASLG), and $10 \mu \mathrm{g}$ of cell extract. CAMP was included in the assay at a concentration of $5 \mu \mathrm{M}$ where indicated. The phosphorylation of Kemptide was determined by spotting $30 \mu \mathrm{l}$ of the incubation mixture on phosphocellulose filters (Whatman, PE81) and washing five times in $0.75 \mathrm{mM}$ phosphoric acid and once in $95 \%$ ethanol. Dried filters were counted by liquid scintillation. To determine PKA-specific kinase activity, all samples were assayed with and without $5 \mu \mathrm{M} \mathrm{PKI}(1-31)$ inhibitor peptide (Scolt et al., 1986; Grove et al., 1987), and noninhibitable kinase activity was subtracted. Linearity of the assay with time and the amount of extract protein were verified.

\section{Northern and Southern Blot Hybridizations}

Total RNA was extracted by the guanidinium isothiocyanate/CsCl cushion method. Agarose-formaldehyde gels were run, transferred, and UV cross-linked to Gene Screen nylon membranes (DuPont) by standard procedures (Sambrogk et al., 1989). Hybridizations with oligonucleotide probes were perfermed overnight at $56^{\circ} \mathrm{C}$ in a solution containing $25 \%$ formamide; $5 \times \mathrm{SSC}, 50 \mathrm{mM}$ sodium phosphate $(\mathrm{pH}$ 
6.5), $8 \times$ Denhardt's solution, $0.5 \mathrm{mg} / \mathrm{ml}$ yeast RNA, $1 \%$ SDS, and 5 $\mu \mathrm{g} / \mathrm{ml}$ poly $(\mathrm{C})$. Filters were washed twice for $5 \mathrm{~min}$ at $50^{\circ} \mathrm{C}-60^{\circ} \mathrm{C}$ in $1 \times$ SSC, $0.1 \%$ SDS and exposed for several days with two intensifying screens. To control the stringency, we estimated the melting temperature $T_{m}$ for oligonucleotide probes from the following equation: $T_{m}=$ $81.5^{\circ} \mathrm{C}+16.6 \log _{10}\left[\mathrm{Na} \mathrm{a}^{\prime}\right]+0.41(\% \mathrm{G}+\mathrm{C})-0.63$ (\% formamide $)-600$ $\mathrm{I}$, where $\mathrm{I}=$ length of the hybrid in base pairs (Bolton and McCarthy, 1962). Conditions for our oligonucleotide probes were $18^{\circ} \mathrm{C}$ below $\mathrm{T}_{m}$ for hybridization and $18^{\circ} \mathrm{C}$ to $28^{\circ} \mathrm{C}$ below $T_{m}$ for washing. Uniformly labeled, single-stranded oligonucleotide probes were synthesized by primer extension as described (Sambrook et al., 1989; section 11.4). In brief, $20 \mathrm{pmol}$ of a 12-mer primer was annealed to $2 \mathrm{pmol}$ of a 45-mer template leaving a 5 bp overhang. After extension with Klenow polymerase and $\sim 100 \mu \mathrm{Ci}$ of dCTP $(3000 \mathrm{Ci} / \mathrm{mmol})$, a 40 -mer singlestranded probe was purified from the 45-mer template on denaturing gels.

Northern hybridizations with riboprobes were performed at $72^{\circ} \mathrm{C}$ in the solution described above, but containing $50 \%$ formamide. Blots were washed three times for $30 \mathrm{~min}$ at $80^{\circ} \mathrm{C}$ in $0.1 \times$ SSC, $1 \%$ SDS

For Scuthern blots, Biodyne B (Pall) membrane was used according to the recommendations of the manufacturer. Hybridization and washing conditions for oligonucleotide probes were exactly as described for Northern blots.

\section{Genomic Footprinting}

Cells $\left(5 \times 10^{7}\right)$ were collected by mild trypsinization and resuspended in $1 \mathrm{ml}$ of serum-free medium before addition of DMS. All subsequent steps were performed according to Becker and Schütz (1988), except that presaturation of vector-specific sequences with sheared, singlestranded vector DNA prior to hybridization was not necessary, as a cDNA probe of high specific activity was synthesized from an RNA template as described (Weih et al., 1988). The probe used (HS127) recognized positions -3516 (Styl) to -3643 (Hhal)

\section{In Vivo Labeling of Cells with [ ${ }^{32} \mathrm{P}$ ]Orthophosphate}

\section{and Immunopurification of CREB}

Cells were grown in $35 \mathrm{~mm}$ dishes and incubated in phosphate-free medium (Flow Laboratories). After $1 \mathrm{hr}$, medium was replaced by phosphate-free medium containing $1 \mathrm{mCi}$ of ${ }^{32} \mathrm{P} J$ orthophosphate (carrier-free, Amersham), cells were labeled for $4 \mathrm{hr}$ at $37^{\circ} \mathrm{C}$, and subsequently induced with $10 \mu \mathrm{M}$ forskolin for $10 \mathrm{~min}$ or treated with $0.1 \%$ ethanol as solvent control. Cells were chilled on ice and washed twice with ice-cold PBS (120 mM NaCl, $28 \mathrm{mM} \mathrm{Na} \mathrm{HPO}_{4}, 2.5 \mathrm{mM}$ $\mathrm{KH}_{2} \mathrm{HPO}_{4}$ [pH 7.3]). Cells were lysed in $400 \mu$ of RIPA buffer ( $250 \mathrm{mM}$ $\mathrm{NaCl}, 50 \mathrm{mM}$ Tris- $\mathrm{HCl}$ [pH 7.8], $20 \mathrm{mM} \mathrm{NaF}, 10 \mathrm{mM} \mathrm{Na} \mathrm{MoO}_{4}$, 5 mM EDTA, $1 \%$ Triton $X-100,0.1 \%$ SDS, $0.5 \%$ sodium deoxycholate) for $30 \mathrm{~min}$ in the cold. Unsoluble material was pelleted by centrifugation at $433,000 \times \mathrm{g}(100,000 \mathrm{rpm}$ in a Beckman TLA100.2 rotor) for $20 \mathrm{~min}$ at $2^{\circ} \mathrm{C}$. Equivalent amounts of soluble protein from supernatants were used for imm unopurification of CREB. The anti-peptide antiserum specific for rat CREB is equivalent to that generated by Gonzalez et al. (1989). One microliter of anti-CREB antiserum was added to $1.5 \mathrm{mg}$ of soluble protein in $400 \mu \mathrm{l}$ and incubated on ice. After $1 \mathrm{hr}$, immunocomplexes were purified using sheep anti-rabbit IgG coupled to paramagnetic beads (Dynal, Hamburg) according to manufacturer's recommendations. After three washing steps, samples were denatured for 10 min at $95^{\circ} \mathrm{C}$ and electrophoresed on a $10 \%$ SDS-polyacrylamide gei according to Laemmli (1970).

\section{Analysis of Tryptic Phosphopeptides}

The radioactively labeled $43 \mathrm{kd}$ band was cut from the gels, fixed for $\geqslant 1 \mathrm{hr}$ in $50 \%$ methanol, $12 \%$ acetic acid, and extensively washed with $\mathrm{H}_{2} \mathrm{O}$. The gel slice was cut into small pieces, equilibrated in $50 \mathrm{mM}$ $\mathrm{NH}_{4} \mathrm{HCO}_{3}$ (pH 8.0) for $30 \mathrm{~min}$ at $37^{\circ} \mathrm{C}$, and digested overnight at $37^{\circ} \mathrm{C}$ with $2 \mu \mathrm{g}$ of trypsin (sequencing grade, Boehringer). Gel pieces were washed once with $200 \mu \mathrm{l}$ of $\mathrm{H}_{2} \mathrm{O}\left(1 \mathrm{hr}, 37^{\circ} \mathrm{C}\right)$ and $200 \mu \mathrm{l}$ of acetonitrile ( $30 \mathrm{~min}$, room temperature), and supernatants were transferred to new tubes. After freezing in liquid nitrogen, the volume was reduced to 200 $\mu l$ in a speed-vac concentrator, and residual SDS was extracted three times with $1 \mathrm{vol}$ of $n$-hexane/isoamylalcohol (1:4). The aqueous phase was lyophilized, and the pellet was resuspended in $\mathrm{H}_{2} \mathrm{O}$ and stored at $-20^{\circ} \mathrm{C}$.
Tryptic phosphopeptides were analyzed by two-dimensional separation on thin layer cellulose plates (Merck). Samples were centrifuged for $10 \mathrm{~min}$ to pellet insoluble material, and supernatants were spotted in $1 \mu \mathrm{l}$ steps onto cellulose plates. Separation in the first dimension was carried out by electrophoresis in $7.8 \%$ acetic acid, $2.2 \%$ formic acid $(\mathrm{pH} 1.9)$ at $4^{\circ} \mathrm{C}$ and at $1000 \mathrm{~V}$ for 30 min with a 2117 Multiphor II Electrophoresis Unit (Pharmacia/LKB) according to manufacturer's recommendations. Chromatography in the second dimension was carried out with n-butanol:pyridine:acetic acid: $\mathrm{H}_{2} \mathrm{O}(35: 50: 15: 60)$ for $3 \mathrm{hr}$. Cellulose plates were dried and exposed for 3 days at $-70^{\circ} \mathrm{C}$.

\section{Acknowledgments}

We thank Michael H. Shapero and R. E. Kelth Fournier for generously providing the deletion hybrids used for the experiment shown in Figure 3 and for unpublished mapping information included in the same figure. We thank G. Stanley McKnight for providing the MT-REV(AB)neo construct, the $\mathrm{Ca}$ and RI $\alpha$ riboprobes, and for communicating unpublished information, W. Schmid for the generous supply of CREB antibody, and $\mathrm{U}$. Walter for the purified catalytic subunit of PKA and stimulating discussions. We gratefully acknowledge $M$. Dürst for genomic DNA from human placenta, $W$. Fleischer for synthesis of oligonucleotides, R. Frank for peptides, A. Schmidt for technical assistance, and C. Schneider for excellent secretarial assistance. We thank C. DeVack, I. Grummt, R. Heilbronn, and W. Schmid for critical reading of the manuscript. This work was supported by grants from the Deutsche Forschungsgemeinschaft (Leibniz-Programm and SFB229) and the Fonds der Chemischen industrie.

The costs of publication of this article were defrayed in part by the payment of page charges. This article must therefore be hereby marked "advertisement" in accordance with 18 USC Section 1734 solely to indicate this fact.

Received March 4, 1991; revised July 9, 1991.

\section{References}

Becker, P. B., and Schütz, G. (1988). Genomic footprinting. In Genetic Engineering, Principles and Methods, Vol. 10, J. K. Setlow, ed. (New York: Plenum Press), pp. 1-19.

Bergman, Y., Strich, B., Sharir, H., Ber, R., and Laskov, R. (1990). Extinction of Ig gene expression in myeloma $x$ fibroblast somatic cell hybrids is accompanied by repression of the oct-2 gene encoding a B-cell specific transcription factor. EMBO J. 9, 849-855.

Bolton, E. T., and McCarthy, B. J. (1962). A general method for the isolation of RNA complementary to DNA. Proc. Natl. Acad. Sci. USA 48, 1390-1397.

Boshart, M., Weih, F., Schmidt, A., Fournier, R. E. K., and Schütz, G. (1990). A cyclic AMP response eloment mediates repression of tyrosine aminotransferase gene transcription by the tissue-specific extinguisher locus Tse-1. Cell 61, 905-916.

Cadd, G., and McKnight, G. S. (1989). Distinct patterns of cAMPdependent protein kinase gene expression in mouse brain. Neuron 3 , 71-79.

Cereghini, S., Yaniv, M., and Cortese, R. (1990). Hepatocyte differentiation and extinction is accompanied by a block in the synthesis of mRNA coding for the transcription factor HNF1/LFB1. EMBO J. 9 , 2257-2263.

Chin, A. C., and Fournier, R. E. K. (1987). A genetic analysis of extinction: trans-regulation of 16 liver-specific genes in hepatoma-fibroblast hybrid cells. Proc. Natl. Acad. Sci. USA 84, 1614-1618.

Chin, A. C., and Fournier, R. E. K. (1989). Tse-2: a trans-dominant extinguisher of albumin gene expression in hepatoma hybrid cells. Mol. Cell. Biol. 9, 3736-3743.

Clegg, C. H., Correll, L. A., Cadd, G. G., and McKnight, G. S. (1987). Inhibition of intracellular CAMP-dependent protein kinase using mutant genes of the regulatory type I subunit. J. Biol. Chem. 262, 1311113119.

Clegg, C. H., Cadd, G. G., and McKnight, G. S. (1988). Genetic characterization of a brain-specific form of the type I regulatory subunit of 
CAMP-dependent protein kinase. Proc. Natl. Acad. Sci. USA 85, 37033707

Correll, L. A., Woodford, T. A., Corbin, J. D., Mellon, P. L., and McKnight, G. S. (1989). Functional characterization of cAMP-binding mutations in type I protein kinase. J. Biol. Chem, 264, 16672-16678. Davidson, R. L. (1974). Gene expression in somatic cell hybrids. Annu. Rev. Genet. 8, 195-218.

Davis, F. M., and Adelberg, E. A. (1973). Use of somatic cell hybrids for analysis of the differentiated state. Bacteriol. Rev. 37, 197-214.

Day, R. N., Walder, J. A., and Maurer, R. A. (1989). A protein kinase inhibitor gene reduces both basal and multihormone-stimulated prolactin gene transcription. J. Biol. Chem. 264, 431-436.

de Wet, J. R., Wood, K. V., DeLuca, M., Helinski, D. R., and Subramani, S. (1987). Firefly luciferase gene: structure and expression in mammalian cells. Mol. Cell. Biol. 7, 725-737.

Drain, P., Folkers, E., and Quinn, W. G. (1991). cAMP-dependent protein kinase and the disruption of learning in transgenic flies. Neuron 6, 71-82.

Dynan, W. S. (1989). Modularity in promoters and enhancers. Cell 58 , $1-4$.

Fort, P., Marty, L., Piechaczyk, M., El Sabrouty, S., Dani, C., Jeanteur, P., and Blanchard, J. M. (1985). Various rat adult tissues express only one major mRNA species from the glyceraldehyde-3-phosphate dehydrogenase multigenic family. Nucl. Acids Res. 13, 1431-1442.

Gonzalez, G. A., and Montminy, M. R. (1989). Cyclic AMP stimulates somatostatin gene transcription by phosphorylation of CREB at serine 133. Cell 59, 675-680.

Gonzalez, G. A., Yamamoto, K. K., Fischer, W. H., Karr, D., Menzel, P., Biggs, W., III, Vale, W. W., and Montminy, M. R. (1989). A cluster of phosphorylation sites on the cyclic AMP-regulated nuclear factor CREB predicted by its sequence. Nature 337, 749-752.

Gourdeau, H., and Fournier, R. E. K. (1990). Genetic analysis of mammalian cell differentiation. Annu. Rev. Cell Biol. 6, 69-94.

Gourdeau, H., Peterson, T. C., and Fournier, R. E. K. (1989). Differential activity of a tissue-specific extinguisher locus in hepatic and nonhepatic cells. Mol. Cell. Biol. 9, 1813-1822.

Greengard, $0 .(1970)$. The developmental formation of enzymes in rat liver. In Mechanism of Hormone Action I, G. Litwack, ed. (New York: Academic Press), pp. 53-85.

Grove, J. R., Price, D. J., Goodman, H. M., and Avruch, J. (1987). Recombinant fragment of protein kinase inhibitor blocks cyclic AMPdependent gene transcription. Science 238, 530-533.

Grove, J. R., Deutsch, P. J., Price, D. J., Habener, J. F., and Avruch, J. (1989). Plasmids encoding PKI (1-31), a specific inhibitor of CAMPstimulated gene expression, inhibit the basal transcriptional activity of some but not all CAMP-regulated DNA response elements in JEG-3 cells. J. Biol. Chem. 264, 19506-19513.

Junker, S., Nielsen, V., Matthias, P., and Picard, D. (1988). Both immunoglobulin promoter and enhancer sequences are targets for suppression in myeloma-fibroblast hybrid cells. EMBO J. 7, 3093-3098.

Junker, S., Pedersen, S., Schreiber, E., and Matthias, P. (1990). Extinction of an immunoglobulin $\kappa$ promoter in cell hybrids is mediated by the octamer motif and correlates with suppression of Oct-2 expression. Cell 61, 467-474.

Killary, A. M., and Fournier, R. E. K. (1984). A genetic analysis of

Krebs, E. G., and Beavo, J. A. (1979). Phosphorylation-dephosphorylation of enzymes. Annu. Rev. Biochem. 48, 923-959.

Kuno, T., Ono, Y., Hirai, M., Hashimoto, S., Shuntoh, H., and Tanaka, C. (1987). Molecular cloning and CDNA structure of the regulatory subunit of type I cAMP-dependent protein kinase from rat brain. Biochom. Biophys. Res. Commun. 146, 878-883.

Laemmli, U. K. (1970). Cleavage of structural proteins during the assembly of the head of bacteriophage T4. Nature 227,680-685.

Leach, R. J., Thayer, M. J., Schäfer, A. J., and Fournier, R. E. K. (1989). Physical mapping of human chromosome 17 using fragmentcontaining microcell hybrids. Genomics 5, 167-176.
Lee, C. Q., Yun, Y., Hoeffler, J. P., and Habener, J. F. (1990). CyclicAMP-responsive transcriptional activation of CREB-327 involves interdependent phosphorylated subdomains. EMBO J. 9, 4455-4465.

Lem, J., Chin, A. C., Thayer, M. J., Leach, R. J., and Fournier, R. E. K. (1988). Coordinate regulation of two genes encoding gluconeogenic enzymes by the trans-dominant locus $T s e-1$. Proc. Natl. Acad. Sci. USA 85, 7302-7306.

McCormick, A., Wu, D., Castrillo, J.-L., Dana, S., Strobl, J., Thompson, E. B., and Karin, M. (1988). Extinction of growth hormone expression in somatic cell hybrids involves repression of the specific trans-activator GHF-1. Cell 55, 379-389.

McGrane, M. M., Yun, J. S., Moorman, A. F. M., Lamers, W. H., Hendrick, G. K., Arafah, B. M., Park, E. A., Wagner, T. E., and Hanson, R. W. (1990). Metabolic effects of developmental, tissue-, and cellspecific expression of a chimeric phosphoenolpyruvate carboxykinase (GTP)/bovine growth hormone gene in transgenic mice. J. Biol. Chem. 265, 22371-22379

McKnight, G. S., Cadd, G. G., Clegg, C. H., Otten, A. D., and Correll L. A. (1988a). Expression of wild-type and mutant subunits of the cAMP-dependent protein kinase. Cold Spring Harbor Symp. Quant. Biol. 53, 111-119.

McKnight, G. S., Clegg, C. H., Uhler, M. D., Chrivia, J. C., Cadd, G. G. Correll, L. A., and Otten, A. D. (1988b). Analysis of the CAMP. dependent protein kinase system using molecular genetic approaches. Rec. Progr. Hormone Res. 44, 307-335.

Mellon, P. L., Clegg, C. H., Correl, L. A., and McKnight, G. S. (1989) Regulation of transcription by cyclic AMP-dependent protein kinase. Proc. Natl. Acad. Sci. USA 86, 4887-4891.

Nitsch, D., Stewart, A. F., Boshart, M., Mestril, R., Weih, F., and Schütz, G. (1990). Chromatin structures of the rat tyrosine aminotransferase gene relate to the function of its cis-acting elements. Mol. Cell Biol. 10, 3334-3342.

Nowak, I., Seipel, K., Schwarz, M., Jans, D. A., and Hemmings, B. A. (1987). Isolation of a cDNA and characterization of the $5^{\prime}$ flanking region of the gene encoding the type I regulatory subunit of the cAMP dependent protein kinase. Eur. J. Biochem. 167, 27-33.

Otten, A. D., and McKnight, G. S. (1989). Overexpression of the type II regulatory subunit of the cAMP-dependent protein kinase eliminates the type I holoenzyme in mouse cells. J. Biol. Chem. 264, 2025520260.

Dyen, O., Sandberg, M., Eskild, W., Levy, F. O., Knutsen, G., Beebe, S., Hansson, V., and Jahnsen, T. (1988). Differential regulation of messenger ribonucleic acids for specific subunits of cyclic adenosine $3^{\prime}, 5^{\prime}$-monophosphate (cAMP)-dependent protein kinase by cAMP in rat Sertoli cells. Endocrinology 122, 2658-2666.

Dyen, O., Myklebust, F., Scott, J. D., Hansson, V., and Jahnsen, T. (1989). Human testis cDNA for the regulatory subunit $R \|_{c}$ of cAMP dependent protein kinase encodes an alternate amino-terminal region. FEBS Lett. 246, 57-64.

Peterson, T. C., and Fournier, R. E. K. (1989). Genetic activity of a trans regulatory locus in hepatoma hybrid cells. Mol. Biol. Med. 6, 109116.

Petit, C., Levilliers, J., Ott, M. O., and Weiss, M. C. (1986). Tissuespecific expression of the rat albumin gene: genetic control of its extinction in microcell hybrids. Proc. Natl. Acad. Sci. USA 83, 2561-2565. Pillus, L., and Rine, J. (1989). Epigenetic inheritance of transcriptional statos in S caraviciaa coll 50 637 647

transferase mRNA by glucocorticoids ánd CAMP in fetal rat liver. Proc. Natl. Acad. Sci. USA 79, 365-368.

Ruppert, S., Boshart, M., Bosch, F. X., Schmid, W., Fournier, R. E. K., and Schütz, G. (1990). Two genetically defined trans-acting loci coordinately regulate overlapping sets of liver-specific genes. Cell 61, 895904.

Sambrook, J., Fritsch, E. F., and Maniatis; T. (1989). Molecular Cloning: A Laboratory Manual (Cold Spring Harbor, New-York: Cold Spring Harbor Laboratory Press).

Sandberg, M., Taskén, K., Øyen, O., Hansson, V., and Jahnsen, T. (1987). Molecular cloning. cDNA structure and deduced amino acid 
sequence for a type I regulatory subunit $\left(\mathrm{R} \|_{\beta}\right)$ of CAMP-dependent protein kinase from human testis. Biochem. Biophys. Res. Commun. 149, 939-945.

Sandberg, M., Levy, F. O., Qyen, O., Hansson, V., and Jahnsen, T. (1988). Molecular cloning, cDNA structure and deduced amino acid sequence for the hormone-induced regulatory subunit $\left(\mathrm{R} \mathrm{II}_{\beta}\right.$ ) of CAMP. dependent protein kinase from rat ovarian granulosa cells. Biochem. Biophys. Res. Commun. 154, 705-711.

Sandberg, M., Skalhegg, B., and Jahnsen, T. (1990). The two mRNA forms for the type I alpha regulatory subunit of cAMP-dependent protein kinase from human testis are due to the use of different polyadenylation site signals. Biochem. Biophys. Res. Commun. 167, 323-330. Scambler, P., Øyen, O., Wainwright, B., Farrall, M., Law, H.-Y., Estivill, X., Sandberg, M., Williamson, R., and Jahnsen, T. (1987). Exclusion of catalytic and regulatory subunits of cAMP-dependent protein kinase as candidate genes for the defect causing cystic fibrosis. Am. J. Hum. Genet. 41, 925-932.

Scott, J. D., Glaccum, M. B., Fischer, E. H., and Krebs, E. G. (1986). Primary-structure requirements for inhibition by the heat-stable inhibitor of the cAMP-dependent protein kinase. Proc. Natl. Acad. Sci. USA $83,1613-1616$

Seamon, K. B., Padgett, W., and Daly, J. W. (1981). Forskolin: unique diterpene activator of adenylate cyclase in membranes and in intact cells. Proc. Natl. Acad. Sci. USA 78, 3363-3367.

Steinberg, R. A., and Agard, D. A. (1981). Turnover of regulatory subunit of cyclic AMP-dependent protein kinase in S49 mouse lymphoma cells. J. Biol. Chem. 256, 10731-10734.

Svoboda, J. (1960). Presence of chicken tumor virus in the sarcoma of the adult rat inoculated after birth with Rous sarcoma virus. Nature $186,980-981$

Taylor, S. S., Buechler, J. A., and Yonemoto, W. (1990). CAMPdependent protein kinase: framework for a diverse family of regulatory enzymes. Annu. Rev. Biochem. 59, 971-1005.

Thayer, M. J., and Fournier, R. E. K. (1989). Hormonal regulation of Tse1-repressed genes: evidence for multiple genetic controls in extinction. Mol. Cell. Biol. 9, 2837-2846.

Thayer. M. J., Lugo, T. G., Leach, R. J., and Fournier, R. E. K. (1990). Regulation of chimeric phosphoenolpyruvate carboxykinase genes by the trans-dominant locus TSE1. Mol. Cell. Biol. 10, 2660-2668.

Triputti, P., Guérin, S., and Moore, D. D. (1988). Two mechanisms for extinction of gene expression in hybrid cells. Science 241, 1205-1207. Uhier, M. D., and McKnight, G. S. (1987). Expression of cDNAs for two isoforms of the catalytic subunit of cAMP-dependent protein kinase. J. Biol. Chem. 262, 15202-15207.

Weih, F., Stewart, A. F., and Schütz, G. (1988). A novel and rapid method to generate single stranded DNA probes for genomic footprinting. Nucl. Acids Res. 16, 1628.

Weih, F., Stewart, A. F., Boshart, M., Nitsch, D., and Schütz, G. (1990). In vivo monitoring of a cAMP-stimulated DNA-binding activity. Genes Dev, 4, 1437-1449.

Wittmaack, F. M., Weber, W., and Hilz, H. (1983). Isoenzymes of cAMP-dependent protein kinase in developing rat liver and in malignant hepatic tissues. Eur. J. Biochem. 129, 669-674.

Woodford, T. A., Correll, L. A., McKnight, G. S., and Corbin, J. D. (1989). Expression and characterization of mutant forms of the type I regulatory subunit of CAMP-dependent protein kinase. J. Biol. Chem. 264, 13321-13328.

Yamamoto, K. K., Gonzalez, G. A., Biggs, W. H., III, and Montminy, M. R. (1988). Phosphorylation-induced binding and transcriptional efficacy of nuclear factor CREB. Nature 334, 494-498

Yu, H., Porton, B., Shen, L., and Eckhardt, L. A. (1989). Role of the octamer motif in hybrid cell extinction of immunoglobulin gene expression: extinction is dominant in a two enhancer system. Cell $58,441-$ 448.

Zaller, D., Yu, H., and Eckhardt, L. (1988). Genes activated in the presence of an immunoglobulin enhancer or promoter are negatively regulated by a T-lymphoma cell line. Mol. Cell. Biol. 8, 1932-1939. 